\title{
Kidney Growth in Normal and Diabetic Mice Is Not Affected by Human Insulin-Like Growth Factor Binding Protein-1 Administration
}

\author{
Vesna Cingel-Ristić, *,1 Bieke F. Schrijvers, $\dagger$ Arlène K. van Vliet,* Ruth Rasch, $\ddagger$ \\ Victor K. M. Han, $\$$ Stenvert L. S. Drop,* and Allan FlyvbJerg $\dagger$ \\ *Laboratory of Pediatrics, Subdivision of Molecular Endocrinology, Erasmus MC, Rotterdam, The \\ Netherlands; †Medical Research Laboratories, Clinical Institute, Aarhus University Hospital, Aarhus, \\ Denmark; $\neq$ Department of Cell Biology, Institute of Anatomy and Electron Microscopy and \\ Stereological Research Laboratory, Aarhus University, Aarhus, Denmark; and \$CIHR Group in Fetal \\ and Neonatal Health and Development, Lawson Research Institute, University of Western Ontario, \\ London, Ontario, Canada
}

\begin{abstract}
Insulin-like growth factor I (IGF-I) accumulates in the kidney following the onset of diabetes, initiating diabetic renal hypertrophy. Increased renal IGF-I protein content, which is not reflected in messenger RNA (mRNA) levels, suggests that renal IGF-I accumulation is due to sequestration of circulating IGF-I rather than to local synthesis. It has been suggested that IGF-I is trapped in the kidney by IGF binding protein 1 (IGFBP-1). We administered purified human IGFBP-1 (hIGFBP-1) to nondiabetic and diabetic mice as three daily sc injections for 14 days, starting 6 days after induction of streptozotocin diabetes when the animals were overtly diabetic. Markers of early diabetic renal changes (i.e., increased kidney weight, glomerular volume, and albuminuria) coincided with accumulation of renal cortical IGF-I despite decreased mRNA levels in 20-day diabetic mice. Human IGFBP-1 administration had no effect on increased kidney weight or albuminuria in early diabetes, although it abolished renal cortical IGF-I accumulation and glomerular hypertrophy in diabetic mice. Increased IGF-I levels in kidneys of normal mice
\end{abstract}

This work was supported by grants from the Dutch Diabetes Research Foundation, the Danish Diabetes Association, the Novo-Nordisk Foundation, the Danish Medical Research Council, the Novo Foundation, the Nordic Insulin Foundation, the Aarhus University Research Foundation, the Eva and Henry Fraenkels Memorial Foundation, and the Institute for the Promotion of Innovation by Science and Technology in Flanders. Part of the study was presented in August 2003 at the fifth International Workshop on IGF-Binding Proteins, Stockholm, Sweden, and published in abstract form.

${ }^{1}$ To whom correspondence should be addressed at Laboratory of Pediatrics, Room Ee1500, Erasmus MC, P.O. Box 1738, 3000 DR Rotterdam, The Netherlands. E-mail: v.cingel@erasmusmc.nl

Received July 27, 2004

Accepted October 19,2004.

$1535-3702 / 05 / 2302-0135 \$ 15.00$

Copyright (C) 2005 by the Society for Experimental Biology and Medicine receiving hIGFBP-1 were not reflected on kidney parameters. IGFBP-1 administration in diabetic mice had only minor effects on diabetic renal changes. Accordingly, these results did not support the hypothesis that IGFBP-1 plays a major role in early renal changes in diabetes. Exp Biol Med 230:135-143, 2005

Key words: diabetes; growth hormone; insulin-like growth factor I; insulin-like growth factor binding protein 1; mouse

\section{$\mathrm{L}$} ong-term diabetes is accompanied by diabetic nephropathy in $15 \%-20 \%$ of patients with type 1 diabetes, and diabetic nephropathy is one of the most frequent causes of end-stage renal failure in developed countries (1). Increased kidney size, glomerular volume, and hyperfiltration are followed by an increase in urinary albumin excretion, mesangial proliferation, and accumulation of extracellular matrix. Progressive glomerular sclerosis leads to proteinuria and progressive renal insufficiency. The involvement of the growth hormone $(\mathrm{GH}) /$ insulin-like growth factor (IGF) axis in diabetic renal complications has been recognized for a long time (2).

IGF-I is a multifunctional polypeptide produced under the influence of pituitary GH (3). The liver produces most of the circulating IGF-I, although physiologically important autocrine and paracrine production occurs within other tissues. The biological functions of IGF-I are mediated by cell surface receptors, particularly by the IGF-I receptor (IGF-IR, also known as the Type 1 IGF receptor). Six highaffinity IGF binding proteins (IGFBP-1 to IGFBP-6) modulate the actions of IGF-I (4). Circulatory IGFBPs carry the major portion of serum IGF-I, neutralizing its hypoglycemic potential, prolonging its half-life, and transporting it to target tissues. Locally synthesized IGFBPs 
modulate the biological effects of IGF-I at the receptor level. In addition, IGFBPs may also have ligand-independent effects (4).

Morphologic and hemodynamic renal changes that occur in the insulinopenic diabetes model produced by streptozotocin (STZ), reflect the changes observed in the course of type 1 diabetes in humans. Following the onset of diabetes, IGF-I accumulates in the kidney, preceding the initiation of renal hypertrophy (5-7). An increased kidney IGF-I protein content, along with unchanged or decreased IGF-I messenger RNA (mRNA) levels, suggest that renal IGF-I accumulation is due to sequestration of circulatory IGF-I rather than to local synthesis (6).

IGF-I may get trapped in the kidney as a consequence of changes in renal IGFBPs. IGFBP-1 is considered a strong candidate both in capturing IGF-I locally and in mediating kidney growth per se. IGF-I and IGFBP-1 colocalize in the same portions of the nephron, in the same cell types, supporting the view that the actions of IGF-I may be modified by IGFBP-1 (8). In early STZ-induced diabetes in rats, cortical IGFBP-1 mRNA is increased (9).

Recently, we reported increased kidney weights after human IGFBP-1 (hIGFBP-1) administration in pituitarydeficient Snell dwarf mice. In addition, hIGFBP-1 coadministered with IGF-I neutralized the stimulating effects of IGF-I on body length and weight, but not on kidney weight (10). These results, suggesting an important role for IGFBP-1 in kidney enlargement, led us to investigate the effects of hIGFBP-1 administration on kidney parameters and regulation of the GH/IGF axis in a diabetic mouse model.

\section{Materials and Methods}

Human IGFBP-1 Isolation and Purification. Human IGFBP-1 was isolated from midgestational amniotic fluid obtained for diagnostic purposes with approval of the Ethics Committee of Sophia Children's Hospital, Rotterdam, The Netherlands, and purified on a Resource RPC 3$\mathrm{ml}$ column connected to a fast protein liquid chromatography (FPLC) System (Automatic FPLC; Pharmacia Biotech, Uppsala, Sweden) as described in detail previously (11).

Animals and Procedures. Adult female NMRI mice aged 8 weeks (Bomholtgaard, Ry, Denmark) with initial body weights of $21.3 \pm 0.9 \mathrm{~g}$ were used. Mice were housed five to six per cage and had free access to standard chow (Altromin 1324; Lage, Germany) and tap water. They were kept at constant temperature $\left(22^{\circ} \pm 2^{\circ} \mathrm{C}\right)$ and humidity $(55 \% \pm 2 \%)$, under a 12:12-hr light:dark cycle (0600-1800 hrs). The study complied with Danish regulations for handling laboratory animals.

The animals were randomized into four groups, two of which were made diabetic: (i) control/placebo (CP, $n=10$ ), (ii) control/hIGFBP-1 (CI, $n=10)$, (iii) diabetic/placebo (DP, $n=15$ ), and (iv) diabetic/hIGFBP-1 (DI, $n=15$ ). After
$12 \mathrm{hrs}$ of food deprivation (all groups), diabetes was induced at Day 0 by a single iv tail-vein injection of STZ ( $\approx 225 \mathrm{mg} / \mathrm{kg}$ body weight) dissolved in $0.154 \mathrm{M} \mathrm{NaCl}(\mathrm{pH}$ $4)$. The animals were weighed, blood glucose levels were measured in tail-vein blood (Precision Xtra; Abbott Laboratories, MediSense Products, Bedford, MA), and urine was examined for glucose and ketone bodies (Neostix-4; Ames, Stoke Poges, Slough, UK) every second day throughout the study. Mice with ketonuria on Day 3 were treated with sustained release insulin implants (Linbit for mice; Linshin Canada, Inc., Scarborough, ON, Canada) to correct ketonuria and prevent massive body weight loss. Mice with blood glucose levels greater than $16 \mathrm{~m} M$ and without ketonuria were included in the study.

Human IGFBP-1 administration was initiated at Day 6, when the animals developed overt diabetes. Human IGFBP1 was administered by three daily sc injections (at 0800 , 1600 , and $2400 \mathrm{hrs}$ ) for 14 days $(0.3 \mathrm{mg} \mathrm{hIGFBP-1/animal} /$ day, based on previous study; Ref. 10), while placebo groups received an equivalent volume of vehicle alone $(0.154 \mathrm{M} \mathrm{NaCl})$ in the same time intervals (Days 6-19). Food consumption was measured per cage and expressed per mouse. Animals were sacrificed at Day 20 after sodium barbital (10 mg/kg body weight) ip anesthesia, exactly $2 \mathrm{hrs}$ after the last hIGFBP-1 injection. Blood was drawn 5 mins later from the retro-orbital venous plexus. Serum was stored at $-80^{\circ} \mathrm{C}$ until analysis. Immediately after extraction, kidneys and liver were weighed, snap-frozen in liquid nitrogen, and stored at $-80^{\circ} \mathrm{C}$. The middle part of the left kidney ( $2 \mathrm{~mm}$ thick) containing the papilla was fixed and embedded in paraffin for morphological measurements and immunohistochemistry.

Immunoassays. Serum GH, serum IGF-I, and renal cortical IGF-I levels were measured by radioimmunoassay as described previously (12). Serum insulin was measured by an ultrasensitive rat insulin enzyme-linked immunosorbent assay (DRG Diagnostics, Marburg, Germany). Semilog linearity of mouse serum and rat insulin was found at multiple dilutions, indicating antigen similarity between mouse and rat insulin. The intraassay and interassay coefficients of variation were $<5 \%$ and $<10 \%$, respectively.

Western Ligand Blotting (WLB) for Determination of Serum and Kidney IGFBPs. Serum samples (2 $\mu \mathrm{l}$ per lane) or tissue homogenates (200 $\mu \mathrm{g}$ per lane) were separated by sodium dodecyl sulfate-polyacrylamide gel electrophoresis (SDS-PAGE) and WLB analysis of serum and renal cortical IGFBPs was executed as described previously (13). The relative densities of the bands were expressed in pixels.

Western Immuno Blotting (WIB) for IGFBP-1 and IGFBP-2. Serum samples $(2 \mu$ per lane) were separated by SDS-PAGE (15\% polyacrylamide) and transferred by electroelution onto nitrocellulose membrane (Schleicher \& Schuell, Munich, Germany). The blots were blocked for $12 \mathrm{hrs}$ at $4^{\circ} \mathrm{C}$ in $5 \%$ nonfat milk and incubated overnight at $4^{\circ} \mathrm{C}$ with a polyclonal goat IGFBP- 1 antibody 
(Santa Cruz Biotechnology, Santa Cruz, CA) in a dilution of $1 / 1000$, or with a polyclonal goat IGFBP-2 antibody (Santa Cruz Biotechnology) in a dilution of 1/1000. The IGFBP-1 antibody cross-reacts both with human and mouse IGFBP-1 (mIGFBP-1). After washing in Tris-buffered saline-Tween $(0.1 \%)$, the membranes were incubated with an anti-goat IgG antibody conjugated with horseradish peroxidase (Pierce, Rockford, IL) for $1 \mathrm{hr}$ at room temperature in a dilution of $1 / 12,000$. The bands were visualized by chemiluminescence (BioWest; UPV Inc., Upland, CA) and quantified by a UPV BioImaging System (UPV Inc.).

Immunohistochemistry. The middle part of the left kidney ( $2 \mathrm{~mm}$ thick) containing the papilla was fixed in neutral buffered $4 \%$ paraformaldehyde and embedded in paraffin. Four-micrometer-thick sections were prepared by standard techniques and mounted on SuperFrost Plus slides (Fisher Scientific, Fairlawn, NJ). Tissue sections were then deparaffinized and rehydrated. Kidney sections were incubated with a polyclonal antibody against human IGF-I (a kind gift from Dr. Peter Gluckman, Liggins Research Institute, Auckland, New Zealand; 14) for $24 \mathrm{hrs}$ at $4^{\circ} \mathrm{C}$. The immunoreactivity was visualized by the avidin-biotinperoxidase technique, using diaminobenzidine as the chromagen (Vectastain; Vector Laboratories, Burlingame, CA). The tissue sections were then counterstained with Carazzi's hematoxylin, dehydrated, and mounted with Permount (Fisher Scientific).

Real-time Polymerase Chain Reaction (PCR). Total RNA was extracted from cortical kidney and liver samples by Trizol Reagent following the instructions of the manufacturer (Gibco BRL-Life Technologies Inc., Gaithersburg, MD). Renal cortical and hepatic GH/IGF system gene expression was analyzed by means of real-time quantitative PCR (TaqMan), as described previously (11). Following complementary DNA synthesis, mRNA levels were quantitatively determined on an ABI Prism 7700 Sequence Detection system (Applied Biosystems, Foster City, CA) using SYBR-green technology. The primers used for mouse hypoxanthine phosphoribosyltransferase (mHPRT), mIGF-I, mIGFBP-1, mIGFBP-3, mouse growth hormone-receptor (mGHR), and mouse growth hormone binding protein (mGHBP) have been reported previously (11). The primer set used for mIGFBP-2 was forward primer, CGCGGGTACCTGTGAAAAGA and reverse primer, CCCTCAGAGTGGTCGTCATCA, resulting in an amplicon size of 77 base pairs (bp). The primer set used for mIGFBP-4 was forward primer, CATCCCCATTCCAAACTGTGA and reverse primer, ACCCCTGTCTTCCGATCCA, resulting in an amplicon size of $110 \mathrm{bp}$. The primer set used for mIGFBP-5 was forward primer, AGACCTACTCCCCCAAGGTCTT and reverse primer, TTTCTGCGGTCCTTCTTCACA, resulting in an amplicon size of $84 \mathrm{bp}$. The primer set used for mIGF-IR was forward primer, GGGATTTCTGCGCCAACA and reverse primer, CGTGGATGACGAAGCCATCT, resulting in an amplicon size of $62 \mathrm{bp}$.
PCR efficiencies for all primer sets were $>95 \%$. All measured values were normalized to mHPRT gene expression.

Estimation of Glomerular Volume. The middle part of the left kidney ( $2 \mathrm{~mm}$ thick) containing the papilla was fixed in $2 \%$ paraformaldehyde, $2.5 \%$ glutaraldehyde, and $0.1 \mathrm{M}$ cacodylate buffer, and embedded in paraffin. Sections $(2 \mu \mathrm{m})$ cut on a rotation microtome (Leica Rotation Microtome RM 2165; Leica, Vienna, Austria) were stained with periodic acid-Schiff and hematoxylin. The thickness of the sections was controlled routinely by a Digital Microcator ND 221 (Heidenhain, Traunreut, Germany) attached to the microscope. In each animal, the mean glomerular tuft volume $\left(\mathrm{V}_{\mathrm{G}}\right)$ was determined from the mean glomerular cross sectional area $\left(\mathrm{A}_{\mathrm{G}}\right)$ by light microscopy at a magnification of $\times 40$ as previously described (12). Profile areas were determined with a two-dimensional version of the nucleator (CAST; Olympus, Copenhagen, Denmark). $A_{G}$ was determined as the average area of a total of 40 to 50 glomerular profiles (capillary tuft omitting the proximal tubular tissue within the Bowman capsule) and $V_{G}$ was calculated from the following equation: $\mathrm{V}_{\mathrm{G}}=\beta / \mathrm{k} \times\left(\mathrm{A}_{\mathrm{G}}\right)^{3 / 2}$, where $\beta=1.38$ is the shape coefficient for spheres (the idealized shape of glomeruli), and $\mathrm{k}=1.1$ is a size distribution coefficient. The measurements were performed in a blinded fashion without the investigator's knowledge of the different groups.

Urinary Albumin and Creatinine Concentration. The urine samples were collected in the morning (0800-1100 hrs) by gentle massage over the lower part of the abdomen and stored at $-20^{\circ} \mathrm{C}$ until analysis was performed. The urinary albumin concentration was determined by radioimmunoassay as previously described (12). The urinary creatinine concentration was measured by an automated technique adapted from the Jaffé reaction and corrected for the prevailing glucose content due to interference in the Jaffé reaction. The intraassay and interassay coefficients of variation were $<5 \%$ and $<10 \%$, respectively, for both assays.

Statistical Analysis. Means were compared by oneway ANOVA followed by pairwise comparisons with the least significant difference method. Serum GH values $<1.3$ were assigned value 1.3, and four groups were tested by a Kruskal-Wallis test, followed by pairwise comparisons by a Mann-Whitney test (SPSS software package; SPSS Inc., Chicago, IL). Results are given as the mean \pm SEM, with $n$ indicating the number of animals studied. Significance was assigned at $P \leq 0.05$.

\section{Results}

Body Weight and Metabolic Parameters. Body weights of mice from control groups steadily increased over the time of the study (Fig. 1A). Diabetic mice weighed significantly less than their respective control groups at all time points considered throughout the study, despite a 

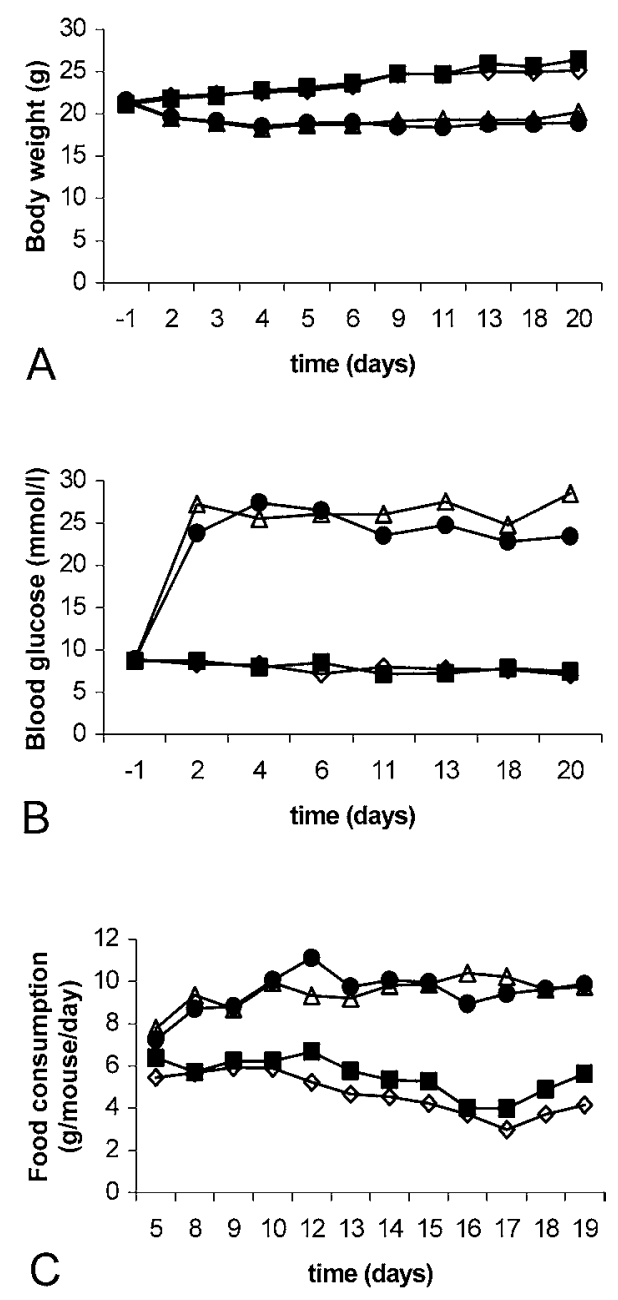

Figure 1. (A) Body weight, (B) blood glucose, and (C) food consumption in nondiabetic mice injected with placebo $(\diamond)$ or hIGFBP-1 (-) and diabetic mice injected with placebo $(\triangle)$ or hIGFBP-1 (•). Values are given as means $(n=10$ for control, $n=$ 15 for diabetic groups).

significantly higher daily food consumption (Fig. 1C). At Day 2, blood glucose levels in diabetic animals were approximately 3 -fold higher than in controls and remained elevated throughout the study period (Fig. 1B). Insulin levels at Day 20 were lower in both diabetic groups compared with their respective controls (Fig. 2C). Injected hIGFBP-1 did not have any influence on mentioned parameters in the control and diabetic groups. Blood glucose levels were significantly decreased in diabetic mice administered hIGFBP-1 only in the last time point measured $(P=0.016)$.

Serum GH, IGF-I, and IGFBPs. In diabetic animals, serum GH levels were significantly increased (Fig. 2A) and IGF-I levels were decreased (Fig. 2B). Whereas hIGFBP-1 had no additional effect on GH serum levels, it further decreased IGF-I serum levels (Fig. 2A and B).

Serum levels of IGFBP-1, detected by WLB, were markedly higher in animals injected with hIGFBP-1, but significantly less elevated in the diabetic group than in the control group (Fig. 2D). On WIB, injected hIGFBP-1 and endogenous mIGFBP-1 were clearly distinguishable by size (Fig. 2E). Mouse IGFBP-1 levels were not different between the groups. Circulating IGFBP-2 levels, detected both on WLB and WIB, were significantly elevated in diabetic animals receiving hIGFBP-1 compared with all other groups (Fig. 2D and E). Serum IGFBP-3 values were lower in diabetic animals compared with their respective controls, and were significantly reduced by hIGFBP-1 injections in both control and diabetic groups (Fig. 2D). Serum IGFBP-4 levels were decreased in both diabetic groups and were significantly increased in normal mice injected with hIGFBP-1 (Fig. 2D).

Kidney Weight, Glomerular Volume, and Urinary Albumin Excretion. Kidney weight is represented as the mean value of both kidneys (Fig. 3A). Kidneys of diabetic mice were significantly heavier than kidneys of their respective nondiabetic controls. Administration of hIGFBP-1, both in the control and diabetic groups, did not have any effect on kidney weight.

Glomerular volume was increased as a consequence of the diabetic state, and injection of hIGFBP-1 decreased it significantly (Fig. 3B). As an indicator of proteinuria the albumin:creatinine ratio $(\mathrm{mg} / \mathrm{mmol})$ was calculated. This ratio was increased in diabetic mice (Fig. 3C). The effect of hIGFBP-1 was not statistically significant.

Kidney IGF-I and IGFBPs. Extractable IGF-I protein content was increased in the renal cortex of diabetic mice receiving placebo (Fig. 4A). In diabetic mice receiving hIGFBP-1, IGF-I protein content was reduced (Fig. 4A). Human IGFBP-1 administration increased IGF-I levels in the kidneys of normal mice (Fig. 4A). Immunostainable IGF-I was clearly visible in both diabetic groups, but was absent in both nondiabetic groups. In diabetic kidneys, IGF-I was predominantly localized in papillary collecting ducts (Fig. 4C) and to some extent in cortical collecting ducts.

Renal cortical IGFBP-1 protein levels were markedly increased in groups receiving hIGFBP-1, and they were higher in diabetic group than in control group (Table 1 and Fig. 4B). IGFBP-2 protein content was higher in kidneys of diabetic animals receiving hIGFBP-1 compared with that of all groups (Table 1). Renal cortical IGFBP-3 protein levels were decreased in both diabetic groups (Table 1). The renal cortical IGFBP-4 protein level was decreased in diabetic mice receiving placebo, with an increase due to hIGFBP-1 administration (Table 1).

Expression of the GH/IGF Axis Genes in Kidney and Liver. Renal cortex IGF-I mRNA concentration was significantly reduced in both diabetic groups (Fig. 5). IGFBP-1 mRNA levels were increased in the control group receiving hIGFBP-1 and decreased in both diabetic groups (Table 1 and Fig. 5). Cortical expression of IGFBP-2 mRNA in kidney was not significantly different between the groups (Table 1). Renal mRNA expression of IGFBP-3 to 

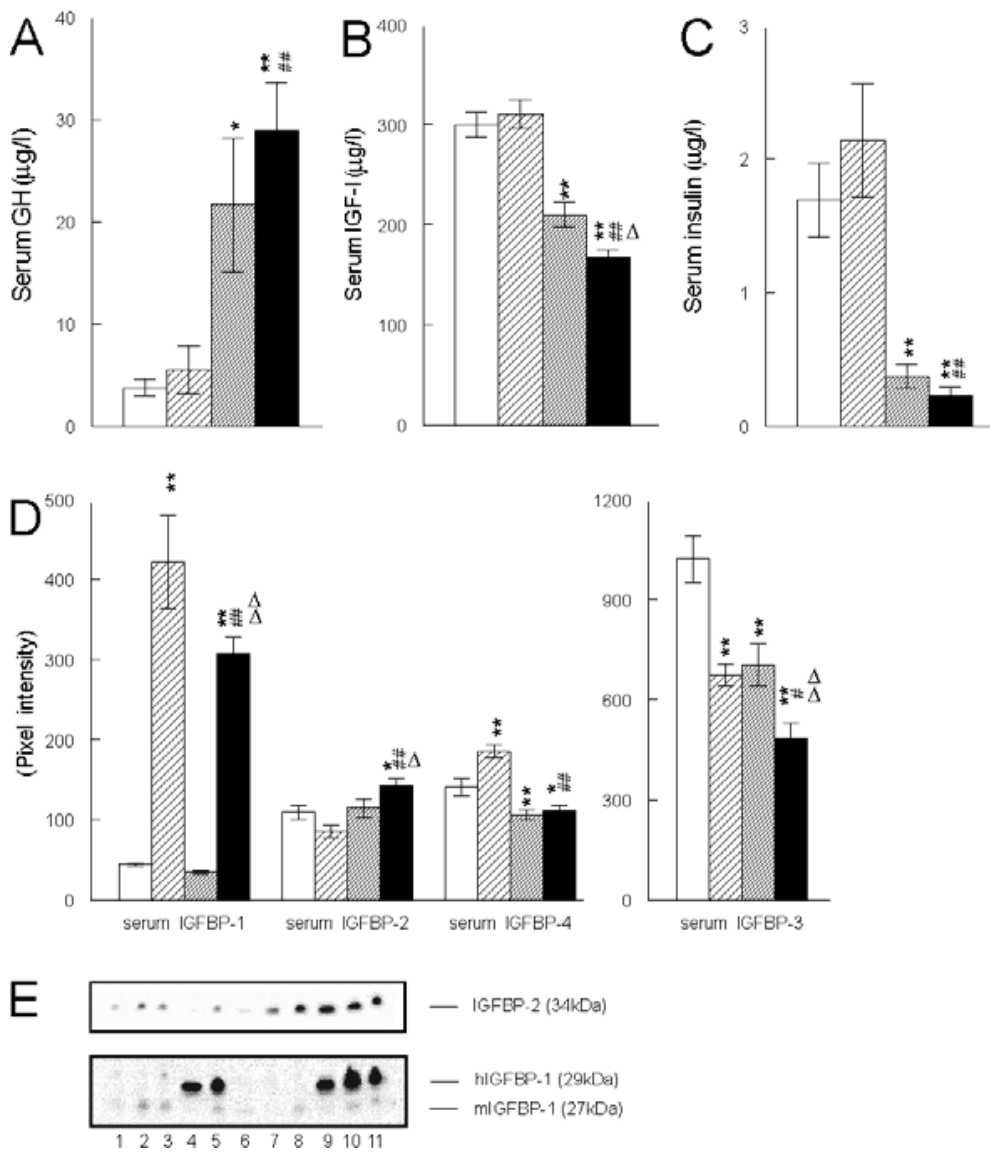

Figure 2. (A) Serum growth hormone (GH), (B) IGF-I, (C) insulin, and (D) IGFBPs (WLB) levels at Day 20 in nondiabetic mice injected with placebo (CP, white bars) or hIGFBP-1 (Cl, light shaded bars), and diabetic mice injected with placebo (DP, dark shaded bars) or hIGFBP-1 (DI, black bars). Values are means \pm SEM $(n=10$ for control, $n=15$ for diabetic groups). $\star \star P \leq 0.005 ; \star P \leq 0.05$ vs. CP group; \#\#P $\leq 0.005$; \#P $\leq 0.05$ vs. Cl group; $\Delta \Delta P \leq 0.005 ; \Delta P \leq 0.05$ vs. DP group. Serum IGFBP-1 (hIGFBP-1, $29 \mathrm{kDa}$; mIGFBP-1, $27 \mathrm{kDa}$ ) and IGFBP-2 (34 kDa) by WIB in CP (lanes 1-3), Cl (lanes 4 and 5), DP (lanes 6-8), and DI (lanes 9-11) groups (E).

IGFBP-5 was decreased in both diabetic groups (Table 1). Levels of renal IGF-IR mRNA were significantly lower in all groups compared with the $\mathrm{CP}$ group $(P<0.001$, data not shown). Expression of $\mathrm{GH}$ receptor mRNA was decreased in the control group receiving hIGFBP-1 ( $P=$ 0.018 , CI vs. CP) and in the diabetic group receiving placebo $(P=0.014$, DP vs. $\mathrm{CP}$, data not shown). $\mathrm{GH}$ binding protein mRNA levels were decreased in kidneys of both diabetic groups $(P \leq 0.001$, DP vs. $\mathrm{CP}$ and DI vs. CI, data not shown).

Hepatic IGF-I mRNA was down-regulated in diabetes and up-regulated in normal mice receiving hIGFBP-1 $(P \leq$ 0.005 , DP vs. CP; $P \leq 0.05$, DI vs. $\mathrm{CI} ; P \leq 0.05$, CI vs. $\mathrm{CP}$, data not shown). Liver IGFBP-1 mRNA levels were
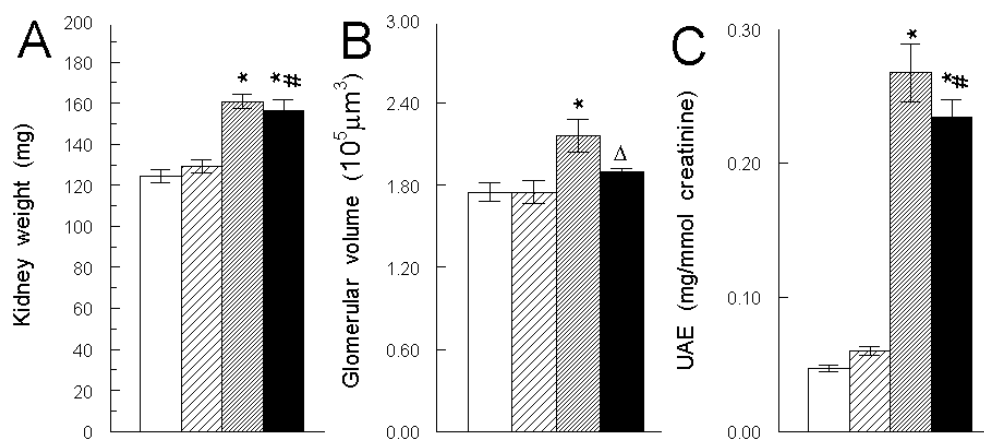

Figure 3. (A) Kidney weight, (B) glomerular volume, and (C) urinary albumin excretion at Day 20 in nondiabetic mice injected with placebo (CP, white bars) or hIGFBP-1 (Cl, light shaded bars) and diabetic mice injected with placebo (DP, dark shaded bars) or hIGFBP-1 (DI, black bars). Values are means $\pm \operatorname{SEM}(n=10$ for control, $n=15$ for diabetic groups). $\star P \leq 0.005$ vs. CP group, $\# P \leq 0.001$ vs. $\mathrm{Cl}$ group, $\Delta P \leq 0.05$ vs. DP group. 


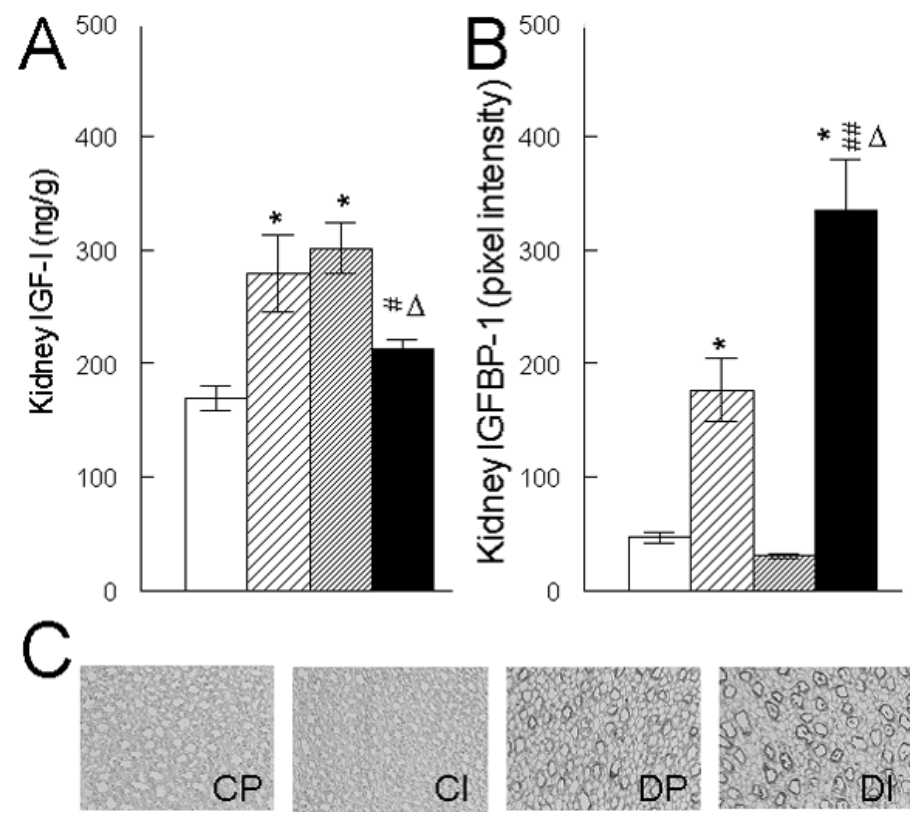

Figure 4. (A) Kidney IGF-I and (B) IGFBP-1 levels and immunostainable IGF-I in papillary collecting ducts $(\times 20)(C)$ at Day 20 in nondiabetic mice injected with placebo (CP, white bars) or hIGFBP-1 (Cl, light shaded bars) and diabetic mice injected with placebo (DP, dark shaded bars) or hIGFBP-1 (DI, black bars). Values are means \pm SEM $[n=10$ for control, $n=15$ for diabetic groups (A); $n=9$ (B)]. $\star P \leq 0.005$ vs. CP group; $\# \# \leq 0.005 ; \# P \leq 0.05$ vs. Cl group; $\Delta P \leq 0.001$ vs. DP group.

significantly increased in diabetic animals receiving hIGFBP-1 compared with those in all groups $(P \leq 0.05$, data not shown). IGFBP-2 mRNA concentration was elevated in diabetic livers $(P<0.001$, DP vs. CP; $P=$ 0.007 , DI vs. CI, data not shown). Hepatic IGFBP-3 mRNA was decreased in diabetic mice $(P=0.001$, DP vs. CP) and restored to control levels when hIGFBP-1 was injected ( $P=$ 0.013 , DI vs. DP, data not shown). Levels of IGFBP-4 and IGFBP-5 mRNA were not different between the groups (data not shown). Expression of $\mathrm{GH}$ receptor and $\mathrm{GH}-$ binding protein mRNA was decreased in livers of both diabetic groups $(P \leq 0.001$, DP vs. $\mathrm{CP}$ and DI vs. CI, data not shown).

\section{Discussion}

The major new finding of this study is that hIGFBP-1 administered for 2 weeks to mice with early STZ-diabetes had no further effect on the increase in kidney weight and albuminuria. However, hIGFBP-1 administration abolished the renal IGF-I accumulation and the increase in glomerular volume in diabetic animals.

The majority of previously published data on the involvement of the IGF system in diabetic renal hypertrophy have been obtained in the STZ-diabetic rat model, which is characterized by growth hormone hyposecretion (2). In contrast, as recently described, the STZ-diabetic mouse model is characterized by GH hypersecretion, thereby being

Table 1. Kidney IGFBPs mRNA and Protein Levels at Day 20 in Nondiabetic and Diabetic Mice Injected with Placebo or hIGFBP-1 ${ }^{a}$

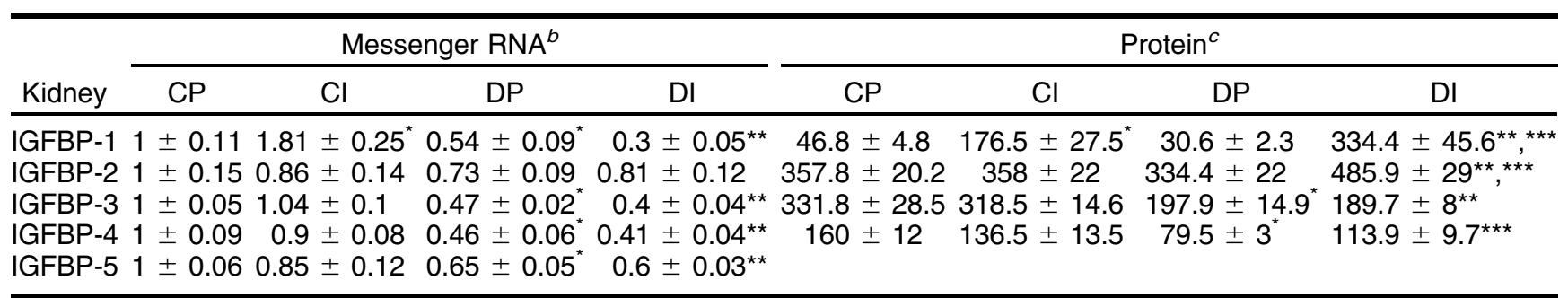

${ }^{a} \mathrm{CP}$, Nondiabetic mice injected with placebo; $\mathrm{Cl}$, nondiabetic mice injected with hIGFBP-1; DP, diabetic mice injected with placebo; DI, diabetic mice injected with hIGFBP-1. Values are means \pm SEM (mRNA, $n=10$; protein, $n=9$ ).

${ }^{b}$ Artificial values, CP value set as 1 .

${ }^{c}$ Protein levels are presented as pixel intensity.

${ }^{\star} P \leq 0.05$ vs. CP group; ${ }^{\star \star} P \leq 0.05$, vs. Cl group; ${ }^{* \star} P \leq 0.05$ vs. DP group. 


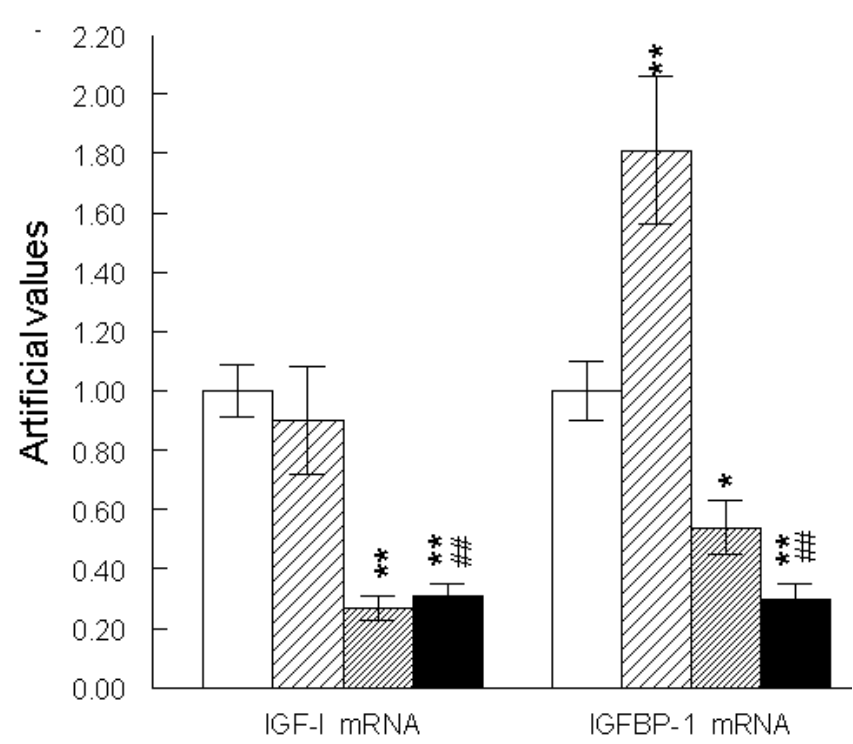

Figure 5. Expression of IGF-I and IGFBP-1 mRNA in kidney at Day 20 in nondiabetic mice injected with placebo (CP, white bars) or hIGFBP-1 (Cl, light shaded bars) and diabetic mice injected with placebo (DP, dark shaded bars) or hIGFBP-1 (DI, black bars). Values are means \pm SEM $(n=10) . \star \star P \leq 0.005 ; \star P \leq 0.05$ vs. CP group; $\# \# P 0.005$ vs. Cl group.

a better model of the changes observed in type 1 diabetes in humans (12). It has been established for a long time that IGF-I accumulates in diabetic kidneys undergoing hypertrophy; however, increased renal IGF-I levels normalize within 4 days after diabetes induction in the STZ rat model, whereas they remain increased up to 4 weeks after diabetes onset in the diabetic mouse $(5,12,15)$. Renal IGF-I accumulation occurs despite unchanged or reduced renal IGF-I mRNA levels, indicating that IGF-I is taken up from the circulation rather than produced locally $(6,9,16,17)$. IGFBP-1, which is elevated in diabetic serum, is believed to have a major role in sequestering circulating IGF-I. While renal IGF-I accumulation in diabetic animals coincided with increased kidney weight, increased glomerular volume, and impairment of the kidney function reflected in higher urinary albumin excretion, none of these changes were observed in nondiabetic mice receiving hIGFBP-1. Although administration of hIGFBP-1 to diabetic mice affected neither the increase in kidney weight nor urinary albumin excretion, it abolished the increase in glomerular volume and blunted renal IGF-I accumulation. This suggests that the renal weight and glomerular volume could be affected by different mechanisms. Human IGFBP-1 administration may affect other relevant factors operating locally in the glomerulus. In line with this, it is of interest that the glomerular hypertrophy observed in both diabetic animals and in those fed high-protein diets, is vascular endothelial growth factor (VEGF)-dependent and that VEGF has been suggested to be a downstream mediator of IGF-I effects (18).

In the present study, renal IGF-I levels were increased in diabetic mice and in nondiabetic mice after hIGFBP-1 administration, although renal IGF-I mRNA levels were down-regulated or unchanged, respectively. Because all samples were collected at Day 20 after diabetes onset, it cannot be excluded that a transient increase in renal IGFBP1 at a time point before Day 20 would play a role in the renal IGF-I accumulation observed in the diabetic kidney. Renal IGF-I content was decreased in diabetic mice after hIGFBP-1 administration. Administration of hIGFBP-1 did not change serum IGF-I levels in control animals, but it did decrease serum IGF-I levels in diabetic animals. Theoretically, the observed lack of effect of IGFBP-1 administration on renal IGF-I accumulation in diabetic mice could be due to lower serum IGF-I levels combined with very high serum IGFBP-1 levels, leading to reduced renal IGF-I uptake.

Both protein content and mRNA levels of IGFBPs were generally unchanged or decreased in the STZ diabetic mouse kidney. This is in contrast with studies reporting increased protein (30 kDa band; IGFBP-1, IGFBP-2, or both) and mRNA levels of IGFBP-1 in 3- to 4-week nonobese diabetic mouse kidney $(15,16,19)$. Detailed investigation of IGFBP mRNA patterns in the diabetic rat kidney showed a reduction in IGFBP-1 expression in the medulla and an increase in the cortex both in short-term (9, 17) and long-term diabetes (9). Our findings are in agreement with studies describing a decrease in renal IGFBP-3 to IGFBP-5 mRNA levels, both in rats and mice $(9,15,17)$. Human IGFBP-1 administration increased the protein content of IGFBPs $-1,-2$, and -4 , whereas it did not change the IGFBPs mRNA expression pattern in the diabetic kidney. In general, unchanged or decreased renal protein content and renal expression of IGFBPs in the STZ diabetic mouse suggest that IGF-I is captured in the kidney by mechanism not involving IGFBPs.

Immunohistochemical studies detected IGFBP-1 colocalized with IGF-I predominantly in the papillary collecting ducts, but also in cortical collecting ducts and medullary thick ascending limbs of Henle's loop in the rat kidney (8). Immunostainable IGFBP-1 shows the same distribution in the mouse kidney (unpublished data). We were not able to specifically detect exogenous hIGFBP-1 due to lack of a suitable human-specific IGFBP-1 antibody. Although extractable renal IGF-I was decreased in diabetic mice and increased in normal mice following hIGFBP-1 administration, we were unable to clearly observe these changes on the immunostained kidney sections. This may be due to the difficulties in using immunohistochemistry for quantification.

Our main aim was to investigate the effect of IGFBP-1 on early changes that take place in the diabetic kidney. Limited availability of purified hIGFBP-1 allowed us only to assess the effect of 2 weeks of hIGFBP-1 administration in early diabetes. Although minipumps would be a more appropriate route for administering hIGFBP-1, they would be insufficient to sustain the required high hIGFBP-1 levels. Because hIGFBP-1 administration in pituitary-deficient 
Snell dwarf mice resulted in a pronounced increase in kidney weight (152\%; Ref. 10), a comparable dose with respect to body weight and the same administration route was used (i.e., three daily sc injections). However, in the present study, hIGFBP-1 did not have any major effects, although increased levels of IGFBP-1 were detected in injected mice, both in serum and kidney. It is possible that in Snell dwarf mice, which lack endogenous GH, and subsequently have very low IGF-I circulatory levels, administered hIGFBP-1 was able to disturb the fragile balance in the GH/IGF axis, whereas in normal mice and diabetic mice, this was not the case. It may be that changes taking place in the diabetic kidney, regarding increased weight and decreased function, are already taking place at a maximal level, so that no effect of IGFBP-1 administration is observed. Further, it cannot be excluded that prolonged administration of hIGFBP-1 would show some additional effect, but in this study, we focused specifically on early renal changes.

Another concern might be the phosphorylation state of the hIGFBP-1 preparation used. It has been shown that elevated serum IGFBP-1 in untreated diabetic patients exists in the highly phosphorylated $(p)$ state (20), a form that in vitro has 4-fold to 6-fold higher affinity for IGF-I than the nonphosphorylated $(n p)$ form (21). Although one might argue that $n p$ IGFBP- 1 is less important than $p$ IGFBP-1, a role for $n p$ IGFBP-1 in the regulation of free IGF-I in vivo has been suggested (22). The purified hIGFBP-1 we administered was approximately $50 \%$ phosphorylated and shown to have renal effects in Snell dwarf mice (10). A recent study involving hIGFBP-1 transgenic (TG) mice and rat (r) IGFBP-1 TG mice exhibiting predominantly $n p$ and $p$ form in the serum, respectively, suggested that the phosphorylation state of IGFBP-1 may account for part of the phenotypic differences such as fasting hyperglycemia and growth restriction in rIGFBP-1 TG but not in hIGFBP-1 TG mice (23). However, another line of hIGFBP-1 TG mice did exhibit growth retardation and glucose intolerance, although to a lesser extent than rIGFBP-1 TG mice, suggesting that if predominantly nonphosphorylated or lesser phosphorylated forms are present in sufficient concentration, hIGFBP-1 could still have an effect (23, 24). It would be interesting in future experiments to study renal changes in diabetic IGFBP-1 TG mice, as well as in IGFBP-1 knockout mice.

In conclusion, hIGFBP-1 administration was shown not to have major effects on early renal changes in diabetes. Further studies are needed to describe the alterations in IGFBPs in the diabetic kidney over time and especially to determine their pathophysiological importance. Some of these questions may be addressed in kidney-specific IGFBPs TG and knockout diabetic mice.

We thank Dr. Jaap Twisk, Division of Biopharmaceutics, Leiden/ Amsterdam Center for Drug Research, Leiden, The Netherlands, for setting up the real-time PCR method. We thank Karen Mathiassen, Kirsten
Nyborg, Ninna Rosenqvist, and Karen Knygard for their excellent technical assistance.

1. Hovind P, Tarnow L, Rossing K, Rossing P, Eising S, Larsen N, Binder C, Parving HH. Decreasing incidence of severe diabetic microangiopathy in type 1 diabetes. Diabetes Care 26:1258-1264, 2003.

2. Flyvbjerg A. Role of growth hormone, insulin-like growth factors (IGFs) and IGF-binding proteins in the renal complications of diabetes. Kidney Int Suppl 60:S12-S19, 1997.

3. Le Roith D, Bondy C, Yakar S, Liu JL, Butler A. The somatomedin hypothesis: 2001. Endocr Rev 22:53-74, 2001.

4. Firth SM, Baxter RC. Cellular actions of the insulin-like growth factor binding proteins. Endocr Rev 23:824-854, 2002.

5. Flyvbjerg A, Thorlacius-Ussing O, Naeraa R, Ingerslev J, Ørskov H. Kidney tissue somatomedin $\mathrm{C}$ and initial renal growth in diabetic and uninephrectomized rats. Diabetologia 31:310-314, 1988.

6. Flyvbjerg A, Bornfeldt KE, Marshall SM, Arnqvist HJ, Ørskov H. Kidney IGF-I mRNA in initial renal hypertrophy in experimental diabetes in rats. Diabetologia 33:334-338, 1990.

7. Flyvbjerg A, Ørskov H. Kidney tissue insulin-like growth factor I and initial renal growth in diabetic rats: relation to severity of diabetes. Acta Endocrinol (Copenh) 122:374-378, 1990.

8. Kobayashi S, Clemmons DR, Venkatachalam MA. Colocalization of insulin-like growth factor-binding protein with insulin-like growth factor I. Am J Physiol 261:F22-F28, 1991.

9. Landau D, Chin E, Bondy C, Domene H, Roberts CT Jr, Gronbaek H, Flyvbjerg A, LeRoith D. Expression of insulin-like growth factor binding proteins in the rat kidney: effects of long-term diabetes. Endocrinology 136:1835-1842, 1995.

10. van Buul-Offers SC, van Kleffens M, Koster JG, Lindenbergh-Kortleve DJ, Gresnigt MG, Drop SL, Hoogerbrugge CM, Bloemen RJ, Koedam JA, Van Neck JW. Human insulin-like growth factor (IGF) binding protein-1 inhibits IGF-I-stimulated body growth but stimulates growth of the kidney in Snell dwarf mice. Endocrinology 141:1493-1499, 2000.

11. Cingel-Ristić V, Van Neck JW, Frystyk J, Drop SLS, Flyvbjerg A. Administration of hIGFBP-1 increases circulating levels of growth hormone in mice. Endocrinology 145:4401-4407, 2004.

12. Flyvbjerg A, Bennett WF, Rasch R, Kopchick JJ, Scarlett JA. Inhibitory effect of a growth hormone receptor antagonist (G120KPEG) on renal enlargement, glomerular hypertrophy, and urinary albumin excretion in experimental diabetes in mice. Diabetes 48:377382, 1999.

13. Flyvbjerg A, Kessler U, Dorka B, Funk B, Ørskov H, Kiess W. Transient increase in renal insulin-like growth factor binding proteins during initial kidney hypertrophy in experimental diabetes in rats. Diabetologia 35:589-593, 1992.

14. Hill DJ, Clemmons DR, Riley SC, Bassett N, Challis JR. Immunohistochemical localization of insulin-like growth factors (IGFs) and IGF binding proteins $-1,-2$ and -3 in human placenta and fetal membranes. Placenta 14:1-12, 1993.

15. Segev Y, Landau D, Marbach M, Shehadeh N, Flyvbjerg A, Phillip M. Renal hypertrophy in hyperglycemic non-obese diabetic mice is associated with persistent renal accumulation of insulin-like growth factor I. J Am Soc Nephrol 8:436-444, 1997.

16. Segev Y, Landau D, Rasch R, Flyvbjerg A, Phillip M. Growth hormone receptor antagonism prevents early renal changes in nonobese diabetic mice. J Am Soc Nephrol 10:2374-2381, 1999.

17. Fervenza FC, Tsao T, Hoffman AR, Rabkin R. Regional changes in the intrarenal insulin-like growth factor-I axis in diabetes. Kidney Int 51:811-818, 1997.

18. Schrijvers BF, Rasch R, Tilton RG, Flyvbjerg A. High protein-induced 
glomerular hypertrophy is vascular endothelial growth factor-dependent. Kidney Int 61:1600-1604, 2002.

19. Landau D, Segev Y, Afargan M, Silbergeld A, Katchko L, Podshyvalov A, Phillip M. A novel somatostatin analogue prevents early renal complications in the nonobese diabetic mouse. Kidney Int 60:505-512, 2001.

20. Frost RA, Bereket A, Wilson TA, Wojnar MM, Lang CH, Gelato MC. Phosphorylation of insulin-like growth factor binding protein-1 in patients with insulin-dependent diabetes mellitus and severe trauma. J Clin Endocrinol Metab 78:1533-1535, 1994.

21. Jones JI, D’Ercole AJ, Camacho-Hubner C, Clemmons DR. Phosphorylation of insulin-like growth factor (IGF)-binding protein 1 in cell culture and in vivo: effects on affinity for IGF-I. Proc Natl Acad Sci U S A 88:7481-7485, 1991.

22. Frystyk J, Grofte T, Skjærbæk C, Ørskov H. The effect of oral glucose on serum free insulin-like growth factor-I and -II in health adults. J Clin Endocrinol Metab 82:3124-3127, 1997.

23. Sakai K, D'Ercole AJ, Murphy LJ, Clemmons DR. Physiological differences in insulin-like growth factor binding protein-1 (IGFBP-1) phosphorylation in IGFBP-1 transgenic mice. Diabetes 50:32-38, 2001.

24. Crossey PA, Jones JS, Miell JP. Dysregulation of the insulin/IGF binding protein-1 axis in transgenic mice is associated with hyperinsulinemia and glucose intolerance. Diabetes 49:457-465, 2000. 